425 嗅神経再生過程における神経ベブチドの発現

安野博樹"，深澤媐二郎"，毛利大介"，阪上雅史"，野口光一"

1)兵庫医科大学耳复咽喉科学教室, 2) 同解剖学满座第二

（目的）哺乳類において㭡神释は常にiurn overを綝り返し、障害を受けても再生する能力を備えていることが知られてい

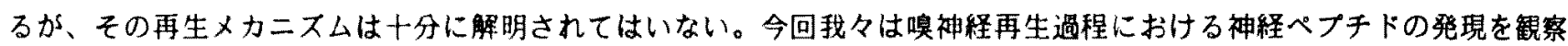
し、若干の知見を得たので文献的考察を加えて報告する。

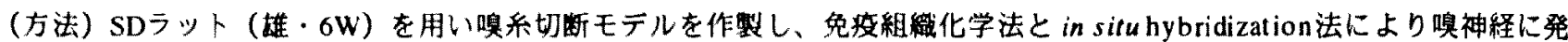
現する神経ペフチドの変化を䠐祭した。神経ペフチドには $\alpha$-CGRP (calcitonin gene-related peptide)、 $\beta$-CGRP、PPT (prepro-tachykinin)を使用した。（結果）再生時にそれそれ巽なるペフチドの発現をみた。

\title{
429 嗅賞刺激に上る脳磁場ゆ反応
}

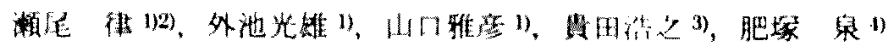

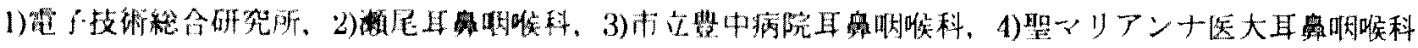

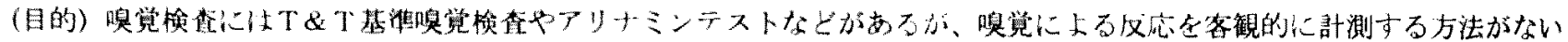

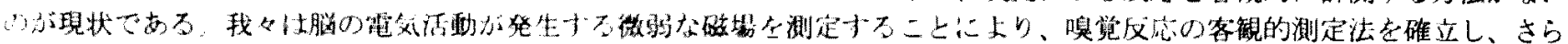

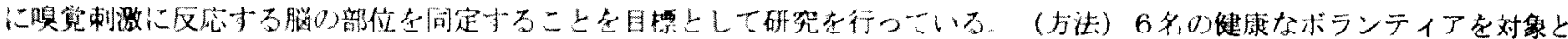

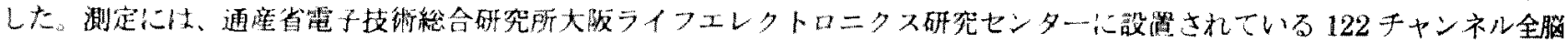

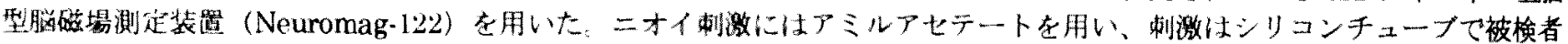

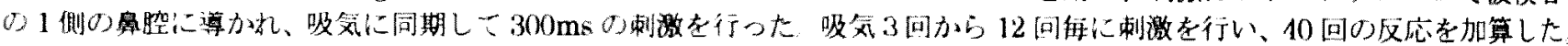

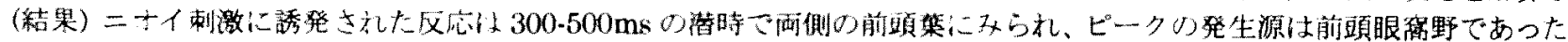

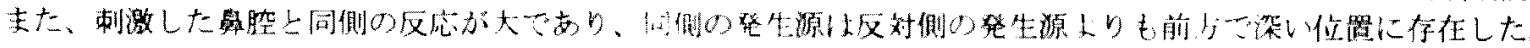

$4 \mathbf{4}$ 二オイ刺激による大䏚誘発反応一刺激条件による差異一

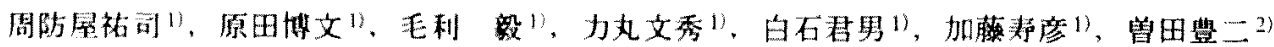

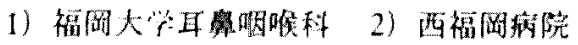

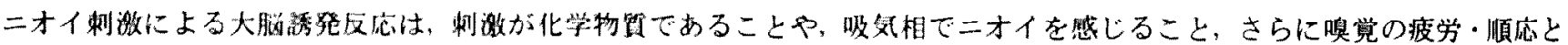
いった問题があるため, その報告はきわめて少ない。しかし交通災害や理境活染などに伴う嗅觉障害の他觉的判定法の確立が 望まれている。今回, 新しく仮想䑙测ソフトウェアパッケージLabVIEWを用いて誘発反応記録装置を構筑し，二才イ剌激に

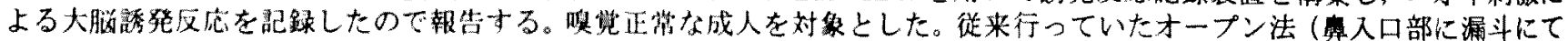

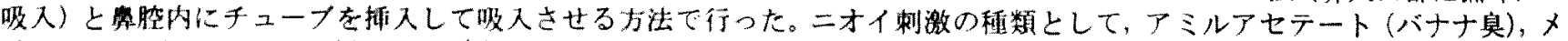
チルシクロペンテノロン(カラメル高) を用いた。

$42 \boldsymbol{8}$ 内視鏡下鼻内手術在行った慢性副鼻腔炎症例の嗅覚障害·嗅粘膜病理所見について

深摆啓二郎、小笠原宽、藤井恵美、安野博槽、阪上雅史

兵庫医科大学耳暞咽喉科

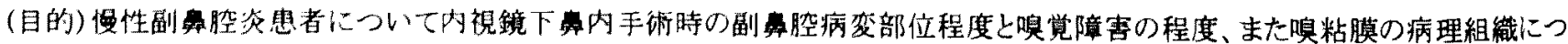

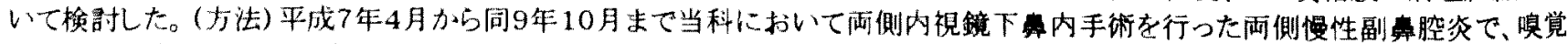

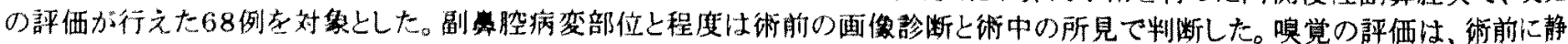

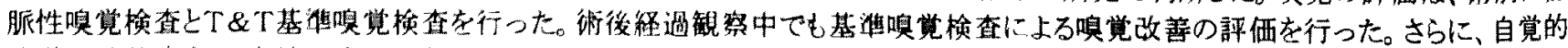

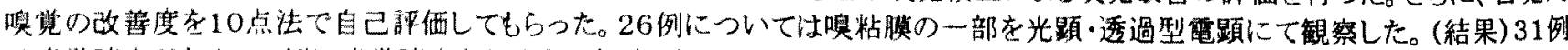

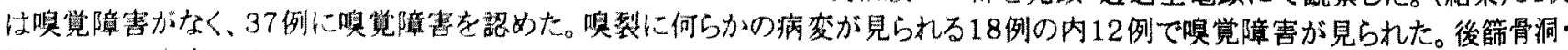

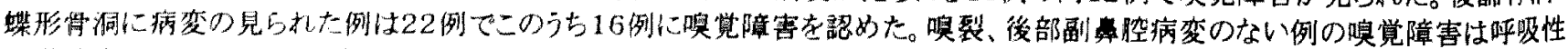

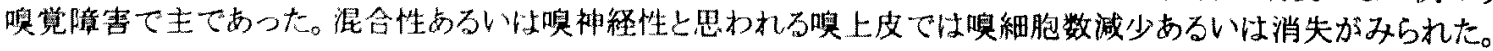

